\title{
Demineralized Bone Matrix
}

National Cancer Institute

\section{Source}

National Cancer Institute. Demineralized Bone Matrix. NCI Thesaurus. Code C61085.

Demineralized allograft bone with osteoinductive activity. Demineralized bone matrices are prepared by acid extraction of allograft bone, resulting in loss of most of the mineralized component but retention of collagen and noncollag enous proteins, including growth factors. The efficacy of a demineralized bone matrix (DBM) as a bone-graft substitute or extender may be related to the total amount of bone morphogenetic protein (BMP) present, and the ratios of the different BMPs present. BMPs belong to the transforming growth factor (T GF) superfamily of proteins. 